\title{
Effect of RNA Interference Hsp72 Gene Expression on Development of Mouse Preimplantation Embryos
}

\author{
WANG Ming-zhi, TIAN Wen-ru, TIAN Zhong-jie, QU Ping-ping, GAO Shan-song, ZHANG Zhi-hong, ZHANG \\ Qi-yao, HOU Chun-xia and LI Hui-hui
}

College of Animal Science and Veterinary Medicine, Qingdao Agricultural University, Qingdao 266109, P.R.China

\begin{abstract}
The method of RNAi was used to inhibit the expression of induced heat shock protein 70 (Hsp72) in the 4-cell stage mouse embryos and the embryo development competence was analyzed to identify the functions of Hsp 72 on embryonic heat resistance. The results indicated that the inhibition rates of siRNA1 for Hsp72 mRNA and Hsp72 protein were 87.1 and 78.5\%, respectively. The blastocysts development rates were 41,86 , and $84 \%$ for the siRNA1 group, the Lipofectamine ${ }^{\mathrm{TM}}$ 2000 exposed group, and the $37^{\circ} \mathrm{C}$ group, respectively, and the hatched blastocysts development rates for the above three groups were 35,72 , and $68 \%$, respectively. The data suggest that the siRNA1 has a significant inhibiting effect on Hsp72 gene, and Hsp72 gene silence reduces the blastocysts development rate and hatched blastocysts rate after heat shock during the development of mouse preimplantation embryos.
\end{abstract}

Key words: RNA interference, mouse, blastocyst, Hsp72 gene

\section{INTRODUCTION}

In recent years, understanding the role of mammalian genes by lossing of their function has been the most successful technique used. Gene-targeted mouse lines have been used extensively to study the function of various genes in mammalian embryogenesis (Paradis et al. 2005). These mouse knockout studies are relatively slow and this tool cannot keep pace with the rapid accumulation of new sequence information produced by the various genome projects. This is because targeted deletion of genes with essential roles in development often results in early embryonic lethality preventing the evaluation of later functions. Antisense RNA was also used for the same purpose in several species (Paradis et al. 2005), but the antisense approaches have not been widely applied to investigate gene function during early development owing to problems associated with non-specific effects and embryo toxicity. Therefore, a technique is needed that can be used to jump directly from sequence to function in a whole animal. For this, the post-transcriptional gene silencing (PTGS) by RNA interference (RNAi) has emerged as a new tool for studying gene function in an increasing number of organisms (Yu et al. 2002).

RNA interference (RNAi) is effective and easy to use in human (Hyslop et al. 2005) and several mammalian species such as mouse (Alizadeh et al. 2005) and porcine (Cabot and Prather 2003), and the cellular mechanisms involved in this process are highly conserved (Denli and Hannon 2003; Gao and Zhang 2007). However, there are very few studies involved in using RNAi on mammalian oocytes and embryos. The first study using RNAi on oocytes was published by two different groups (Svoboda et al. 2000; Wianny and

Received 23 May, 2008 Accepted 20 August, 2008

WANG Ming-zhi, E-mail: xuefeilong111@126.com; Correspondence TIAN Wen-ru, Professor, Tel: +86-532-86080849, E-mail: wrtian@yahoo.com.cn 
Zernicka-Goetz 2000) in 2000 and both provided evidence that the injection of dsRNA in mouse oocytes interfered with the expression of the targeted genes at the mRNA level. Since then, a limited number of studies using RNAi have been done on mouse oocytes and embryos (Stein et al. 2003; Xu et al. 2003) and on pig embryos (Cabot and Prather 2003).

Heat shock protein (Hsp) is a kind of protein that can be rapidly synthesized by an organism in the condition of heat stress. The $70 \mathrm{kDa}$ in Hsp70s represent the most diverse and intensively studied family of stress proteins expressed in embryos, especially the induced heat shock protein 70 (Hsp72) (Kim et al. 2006b). In general, Hsp70s are thought to function as chaperones to other proteins, assisting in protein synthesis, intracellular and transmembrane transport, and assembly of proteinaceous structures (Chung et al. 2008).

Over the past two decades, a number of laboratories have examined the expression and potential functions of Hsp70s in mammalian preimplantation embryos both in vivo and in vitro. It was found that the mortality of preimplantation embryos increased when the pregnant mammals were under the condition of heat stress (Matsuzuka et al. 2004, 2005), and the conception rate increased when heat stress was mitigated in summer (Ewards et al. 2001). Also, the embryonic developmental rate and hatched blostocyst rate reduced when embryos were exposed to high temperature in vitro (Ozawa et al. 2003; Tian et al. 2004). These results indicate that heat stress has a lethal effect on the embryos both in vivo and in vitro. The interesting thing is that while some of the embryos cultured in vitro under the same condition of heat stress can develop to the blastocysts stage, others cannot. The reason presumed by some scholars is owing to the different amounts of Hsp72 synthesized after heat shock (Thayer and Mirkes 1997). Cells enhance their heat resistance following increase in Hsp72, and reduce their heat resistance following decrease in Hsp72 (Dix et al. 1998).

The mechanism of how Hsp72 helps embryos to resist heat is not clear presently; however, it is clear that the biological characteristics of Hsp72 can be ascertained by regulating (increase or reduce) the expression of Hsp72 in preimplantation embryos artificially. The study was carried out to determine whether expression of Hsp72 is required for the development of preimplantation embryo to protect the embryo from le- thal effect of heat stress. To accomplish this, the technique of RNAi was used to inhibit the expression of Hsp72 mRNA in 4-cell mouse embryos. The expression levels of Hsp72 mRNA and Hsp72 proteins were examined in the gene silencing blastocysts and the developmental competence of these embryos was assessed.

\section{MATERIALS AND METHODS}

\section{Embryo collection}

Sexual maturated Kunming (KM) mice (8-10 weeks old) were purchased from the Experimental Animal Center of Shandong University in China. The mice were housed in polysulfone cages (dimensions: $18.4 \mathrm{~cm} \mathrm{~W} \times$ $29.2 \mathrm{~cm} \mathrm{D} \times 12.7 \mathrm{~cm} \mathrm{H}$ ) and maintained under a $14 \mathrm{~h}$ light and $10 \mathrm{~h}$ dark photo-cycle (lights on at 06:00) with water and food supplied ad libitum. During nonmating periods, four female mice were housed per cage, and during mating, two females were housed with one male. After a week's accommodated breeding, females were superovulated by injecting $10 \mathrm{IU}$ of pregnant mare's serum gonadotropin (PMSG), followed $48 \mathrm{~h}$ later by $10 \mathrm{IU}$ of human chorionic gonadotropin (HCG) (both hormones obtained from Ningbo Sansheng Pharmaceutical Co., Ltd., Ningbo, China). Females were then caged with males. Conception was assessed by the presence of a coital plug the following morning. One-cell zygotes were collected from oviducts by tearing the ampulla region with fine forceps in CZB medium (Yu et al. 2005) containing hyaluronidase (1 mg $\mathrm{mL}^{-1}$, Sigma, USA), washed with fresh CZB media, and then cultured in CZB medium containing 0.5\% BSA (Sigma) under paraffin oil (Sigma) in sterile culture dishes in an atmosphere of $5 \% \mathrm{CO}_{2}$ in air at $37^{\circ} \mathrm{C}$. In the late afternoon of day 2 when embryos reached a 4cell stage, they were washed several times and transferred to CZB medium supplemented with glucose (1 $\mathrm{mg} \mathrm{mL}^{-1}$, Sigma).

\section{siRNA preparation}

Three pairs of 21-nucleotide siRNAs were chemically synthesized (Shanghai GenePharma Co., Ltd., Shanghai, China) and delivered in a desalted, deprotected, and 
annealed form. The siRNA target sequence for mouse Hsp72 (GenBank accession no. XM_001004999) was from position 188 to 206 (sense Hsp72-siRNA1, 5'CGC AGA ACA CCG UGU UCG ATT-3' and antisense Hsp72-siRNA1, 5'-UCG AAC ACG GUG UUC UGC GTT-3'). For the positive control of Lamin A (NM_019390), the target sequence was from position 260 to 278 (sense Lamin A-siRNA2, 5'-GAA GCA GCU UCA GGA UGA GdTdT-3' and antisense Lamin AsiRNA2, 5'-CUC AUC CUG AAG CUG CUU CdTdT$\left.3^{\prime}\right)$. The Lamin $A$ gene was also used as an internal standard for the efficiency of the RT-PCR reactions. The negative control siRNA3 has no relation with mouse gene (sense siRNA3, 5'-UUC UCC GAACGU GUCACG UTT-3' and antisense siRNA3, 5'-ACG UGA CAC GUU CGG AGA ATT-3').

\section{Transfection and heat stress}

Each siRNA (100 pmol) was diluted into glucose-CZB $(100 \mu \mathrm{L})$ medium in centrifuge tube $(1.5 \mathrm{~mL})$ and mixed gently. Then, $15 \mu \mathrm{L}$ Lipofectamine ${ }^{\mathrm{TM}} 2000$ (Invitrogen Co., Grand Island, NY, USA) was diluted into glucoseCZB $(100 \mu \mathrm{L})$ medium in another tube and incubated for $5 \mathrm{~min}$ at room temperature after gentle mixing. Diluted Lipofectamine ${ }^{\mathrm{TM}} 2000$ was then added by dropping into the diluted siRNA. This was mixed gently and incubated for $15 \mathrm{~min}$ at room temperature to allow siRNA-Lipofectamine ${ }^{\mathrm{TM}} 2000$ complexes to form. Approximately $0.8 \mathrm{~mL}$ glucose-CZB was added into the complexes to bring the final concentration of the siRNA to $100 \mathrm{nmol} \mathrm{L}^{-1}$. The mixture was then made into 50 $\mu \mathrm{L}$ microdrops under paraffin oil in sterile culture dishes in an atmosphere of $5 \% \mathrm{CO}_{2}$ in air at $37^{\circ} \mathrm{C}$. The embryos were washed several times and transferred to the microdrops (50 embryos per drop) when they reached 4-cell stage and then transferred to normal glucose-CZB (without siRNA and Lipofectamine ${ }^{\mathrm{TM}} 2000$ ) $6 \mathrm{~h}$ later. When the embryos reached the early blastocyst stage, they were heat stressed in $6 \% \mathrm{CO}_{2}$ in air at $41^{\circ} \mathrm{C}$ for $2 \mathrm{~h}$. The stressed blastocysts were then collected for RT-PCR and Western blot.

\section{RT-PCR}

For each treatment, the total RNA was extracted using the Tissue/Cell RNA Mini Kit (Watson Biotechnologies, Shanghai, China). The mRNA was reverse transcribed before PCR amplification by specific primers. All RTPCR reactions were conducted in $200 \mu \mathrm{L}$ PCR tubes and were assembled on ice. For the RT reaction, RNA ( $5 \mu \mathrm{L}$ of final RNA pellet for embryos) was mixed with $2 \mu \mathrm{L} 10$-strength RT-PCR buffer $\left(100 \mathrm{mmol} \mathrm{L}^{-1}\right.$ Tris- $\mathrm{HCl}, \mathrm{pH} 8.3,500 \mathrm{mmol} \mathrm{L}^{-1} \mathrm{KCl}, 15 \mathrm{mmol} \mathrm{L}^{-1}$ $\mathrm{MgCl}_{2}$, TaKaRa, Dalian, China), $2 \mu \mathrm{L}$ of oligo(dT) ${ }_{18}$ (50 mmol L-1 , TaKaRa), $4 \mu \mathrm{L}$ dNTP mix $\left(2.5 \mathrm{mmol} \mathrm{L}^{-1}\right.$ ATP, $2.5 \mathrm{mmol} \mathrm{L}^{-1} \mathrm{CTP}, 2.5 \mathrm{mmol} \mathrm{L}^{-1} \mathrm{TTP}$, and 2.5 mmol L-1 GTP, TaKaRa), and DEPC (Amresco, USA)treated water (to $20 \mu \mathrm{L}$ ). Samples were placed in a thermocycler and incubated at $80^{\circ} \mathrm{C}$ for $3 \mathrm{~min}$ and then cooled to $4^{\circ} \mathrm{C}$. Tubes were returned to the crushed ice, and $1 \mu \mathrm{L}$ of Ribonuclease inhibitor $\left(40 \mathrm{U}_{\mu} \mathrm{L}^{-1}\right.$, TaKaRa) and $1 \mu \mathrm{L}$ of reverse transcriptase $\mathrm{XL}\left(5 \mathrm{U}_{\mu} \mathrm{L}^{-1}\right.$, TaKaRa) were added. Samples were then returned to the thermocycler and incubated at $42^{\circ} \mathrm{C}$ for $1 \mathrm{~h}$ and then at $92^{\circ} \mathrm{C}$ for $10 \mathrm{~min}$; tubes were then cooled to $4^{\circ} \mathrm{C}$. RT products were either stored at $-20^{\circ} \mathrm{C}$ or were used immediately for the PCR step. For amplification, PCR reactions were prepared on ice and conducted in a total volume of $50 \mu \mathrm{L}$, which contained $3 \mu \mathrm{L}$ cDNA product, $4 \mu \mathrm{L} 10$-strength RT-PCR buffer ( $\mathrm{pH} 8.3$, containing $1.5 \mathrm{mmol} \mathrm{L}^{-1} \mathrm{Mg}^{2+}$, TaKaRa), $4 \mu \mathrm{L}$ dNTP mix (TaKaRa), $1 \mu \mathrm{L}\left(5 \mathrm{mmol} \mathrm{L}^{-1}\right)$ of each primer, 35.5

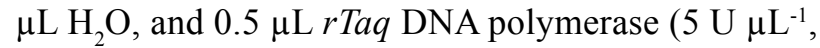
TaKaRa). Tubes were then placed in a programmable thermocycler (PTC-200 PCR, Bio-Rad, USA) and preheated at $94^{\circ} \mathrm{C}$ for $5 \mathrm{~min}$ before 30 cycles of heating at $94^{\circ} \mathrm{C}$ for $1 \mathrm{~min}, 60^{\circ} \mathrm{C}$ for $1 \mathrm{~min}$, and $72^{\circ} \mathrm{C}$ for $1 \mathrm{~min}$. The PCR tubes were then heated at $72^{\circ} \mathrm{C}$ for $7 \mathrm{~min}$ and cooled to $4^{\circ} \mathrm{C}$ until electrophoresis.

Primers were designed as follows: Hsp72 (GenBank accession no. XM_00100499) forward 5'-TCA CGG TGC CCG CCT ACT TC-3' (5' position $=431)$, and reverse 5'-CGC TTG TTC TGG CTG ATG TCC T-3' (3' position=773). Lamin A (GenBank accession no. NM_019390) forward 5'-CGT GTG GCG GTA GAG GAA GTC G-3' (5' position = 1034), and reverse 5'AAG TCA GTA GGG GGG CTA TGG GTG-3' (3' position $=1255$ ). Both of the predicted optimum annealing temperature was $60^{\circ} \mathrm{C}$, and the predicted band sizes were 343 base pairs (bp) and 224 bp, respectively. Reaction products $(10-12 \mu \mathrm{L}$; volume 
was varied slightly to adjust for differences in number of embryos extracted) were resolved on $2 \%(\mathrm{w}: \mathrm{v})$ agarose gels and stained with ethidium bromide $(0.5 \mathrm{~g}$ $\left.\mathrm{L}^{-1}\right)$. The gel was scanned in an image acquisition and analysis system (GDS-8 000, USA), and the optical intensity was quantified with the Glyko Band Scan 5.0 software.

\section{Western blot analysis}

The proteins were extracted in $10 \mu \mathrm{L}$ 2-strength SDS loading buffer (100 mmol L-1 Tris-HCl, $\mathrm{pH} 6.8,4 \%$ SDS, $2 \% \beta$-mercaptoethanol, $20 \%$ glycerine, $0.2 \%$ bromchlorphenol blue). The samples were boiled and separated on a $10 \%$ SDS-PAGE gel, and the proteins were then transferred at $4{ }^{\circ} \mathrm{C}$ for $2 \mathrm{~h}$ at $110 \mathrm{~mA}$ on a nitrocellulose membrane. The membrane was blocked with $5 \%$ bovine serum albumin (diluted by TBST: $0.24 \%$ Tris-base, $0.8 \% \mathrm{NaCl}, 0.1 \%$ Tween20) for $2 \mathrm{~h}$ under room temperature, and was washed three times for $5 \mathrm{~min}$ in TBST. Then, the membrane was incubated at $4{ }^{\circ} \mathrm{C}$ overnight with the primary antibody Anti-Hsp70 (SPA-810, Stressgen Co., Canada). The antibody was diluted 1:1000 in TBST. After the incubation with the primary antibody, the membrane was washed three times for $5 \mathrm{~min}$ in TBST and the hybridization with the secondary antibody was performed at room temperature for $1 \mathrm{~h}$. The secondary antibody, a goat anti-mouse-HRP (BA1050, Boster Biotechnology, Wuhan, China) was diluted 1: 3000 in TBST prior to use. The membrane was finally rinsed once for $15 \mathrm{~min}$ in TBST and three more times for 5 min under the same conditions. The immunoreactive bands were detected by KCTM General Western Blot Detection Kit (KC-420, KangChen Bio-tech, Shanghai, China). Western stripping buffer (P0025, Beyotime Biotechnology, Haimen, China) was used to wash down the antibodies prior to adding on the membrane. Tubulin was used as an internal standard for the efficiency of the Western blot reactions. The steps were similar to that described above for blocking, the difference being the density of Tubulin primary antibody (AT818, Beyotime Biotechnology, Haimen, China), which was 1:500 in this case. Quantitation of the optical intensity was performed by densitometric analysis using the Glyko
Band Scan 5.0 software.

\section{Assessment of developmental competence}

The percentages of blastocysts developed from 4-cell stage embryos were recorded at $48 \mathrm{~h}$ after the siRNAs were transfected, and the percentages of hatched blastocysts (including the hatching and hatched blastocysts) were recorded at $48 \mathrm{~h}$ after heat stress. The experiments were repeated 3 times, and 100 embryos were used in each repetition.

\section{Statistical analysis}

The statistical significance of the differences in the Hsp72 transcript levels between the samples was tested using the statistical analysis system (SAS) ver. 8.0 (SAS Institute Inc., NC, USA) software package. Differences in mean values between two or more experimental groups or developmental stages were tested using ANOVA. Differences of $P<0.05$ were considered to be significant.

\section{RESULTS}

\section{RT-PCR for Hsp72}

RT-PCR of RNA extracted from blastocysts resulted in synthesis of a $343 \mathrm{bp}$ amplicon corresponding to the

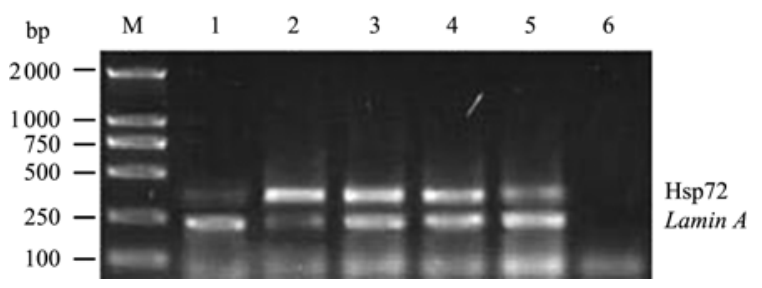

Fig. 1 Hsp72 mRNA level in each group detected by RT-PCR. RNA was extracted from groups of 50 blastocysts. Lanes: 1 , transfected with Hsp72-siRN1; 2, transfected with Lamin A-siRNA2 (positive control); 3 , transfected with siRNA3 (negative control); 4, only Lipofectamine ${ }^{\mathrm{TM}} 2000$ was transfected (blank control group); $5,37^{\circ} \mathrm{C}$ group; 6 , no template group; $\mathrm{M}$, DL 2000 marker (TaKaRa, Dalian, China). Lanes 1-4 were heat-stressed groups, the blastocysts were heat stressed in $6 \% \mathrm{CO}_{2}$ in air at $41^{\circ} \mathrm{C}$ for $2 \mathrm{~h}$ before the RNA were extracted. The blastocysts of $37^{\circ} \mathrm{C}$ group were cultured in $5 \% \mathrm{CO}_{2}$ in air at $37^{\circ} \mathrm{C}$ before the RNA were extracted. 
predicted size for Hsp72 mRNA (Fig.1). The relative contents of Hsp72 mRNA expression in each group were analyzed (Table 1). In the heat stressed groups, the expression of Hsp72 mRNA in the positive control group, negative control group, and blank control group was significantly higher $(P<0.01)$ than that in the $37^{\circ} \mathrm{C}$ group, while in the siRNA1 group, it was significantly lower $(P<0.01)$ than that in the $37^{\circ} \mathrm{C}$ group. The expression of Hsp72 mRNA in the siRNA1 group was significantly lower $(P<0.01)$ than that in the positive control, negative control, and blank control groups. However, there was no significant difference $(P>0.05)$ among the three control groups. The RT-PCR still resulted in synthesis of a $224 \mathrm{bp}$ amplicon corresponding to the predicted size for Lamin A mRNA (Fig.1). The expression of Lamin A mRNA in the positive control group was significantly lower $(P<0.01)$ than that in the other 4 groups, and there was no significant difference $(P>0.05)$ among the 4 groups. The inhibition rate of siRNA1 for Hsp72 mRNA was $87.1 \%$ compared with the blank control group (Table 1).

\section{Western blot analysis of Hsp72}

Hsp72 and Tubulin protein bands were detected by Western blot in all the groups (Fig.2). The gray scale of Hsp72 and Tubulin protein in each group was analyzed (Table 2). In the heat stressed groups, the expression of Hsp72 protein in the positive control group, negative control group, and blank control group was significantly higher $(P<0.01)$ than that in the $37^{\circ} \mathrm{C}$ group, while in the siRNA1 group, it was significantly lower $(P<0.01)$ than in the $37^{\circ} \mathrm{C}$ group. The expression of Hsp 72 protein in the siRNA1 group was significantly lower $(P<0.01)$ than that in the positive control, negative control, and blank control groups. However, there was no significant difference $(P>0.05)$ among the three control groups. The expression of Tubulin had no significant difference $(P>0.05)$ among the other groups. The inhibition rates of siRNA1 for Hsp72 protein was $78.3 \%$ compared with the blank control group (Table 2).

\section{Development rate of the embryos}

The blastocysts development rate in the siRNA1 group was significantly lower $(P<0.05)$ than that in the blank control group and $37^{\circ} \mathrm{C}$ group. However, there was no significant difference $(P>0.05)$ between the blank control group and $37^{\circ} \mathrm{C}$ group. The hatched blastocysts development rate in the siRNA1 group was significantly lower $(P<0.05)$ than that in the blank control group and $37^{\circ} \mathrm{C}$ group, and there was no significant difference $(P>0.05)$ between the blank control group and $37^{\circ} \mathrm{C}$ group (Table 3 ).

Table 1 Relative contents of Hsp72 mRNA expression in each group of embryo

\begin{tabular}{|c|c|c|c|c|}
\hline \multirow{2}{*}{ Groups } & \multicolumn{2}{|c|}{$\begin{array}{l}\text { Optical intensity of } \\
\text { the bands }\left(\times 10^{6}\right)\end{array}$} & \multirow{2}{*}{$\begin{array}{l}\text { Hsp72/ } \\
\text { Lamin A }\end{array}$} & \multirow{2}{*}{$\begin{array}{l}\text { Inhibit } \\
\text { rate }(\%)\end{array}$} \\
\hline & Hsp72 & Lamin $A$ & & \\
\hline siRNA1 & $11.84 \pm 0.86 \mathrm{a}$ & $76.62 \pm 1.22 \mathrm{Aa}$ & $0.15 \pm 0.06 \mathrm{a}$ & 87.1 \\
\hline siRNA2 & $89.04 \pm 1.25 \mathrm{Ab}$ & $31.01 \pm 0.94 \mathrm{~b}$ & $2.87 \pm 0.05 \mathrm{~b}$ & - \\
\hline siRNA3 & $88.85 \pm 1.37 \mathrm{Ab}$ & $76.56 \pm 1.19 \mathrm{Aa}$ & $1.16 \pm 0.03 \mathrm{Ac}$ & - \\
\hline Blank control & $88.54 \pm 1.29 \mathrm{Ab}$ & $76.62 \pm 1.26 \mathrm{Aa}$ & $1.16 \pm 0.03 \mathrm{Ac}$ & - \\
\hline $37^{\circ} \mathrm{C}$ & $25.26 \pm 0.88 \mathrm{c}$ & $76.80 \pm 1.25 \mathrm{Aa}$ & $0.33 \pm 0.06 \mathrm{~d}$ & - \\
\hline
\end{tabular}

Values are means $\pm \mathrm{SD} ; \mathrm{n}=3$ samples per group. The calculation formula for $\mathrm{Hsp} 72$ mRNA inhibition ratio is as follows: [1-(Hsp72/Lamin $\left.A)_{\mathrm{n}} /(\operatorname{Hsp} 72 / \text { Lamin } A)_{\text {blank }}\right]$ $\times 100 \%$. Mean values with the same large letters in a column indicate no significant difference $(P>0.05)$, and with different small letters indicate significant difference $(P<0.01)$. The same as below.

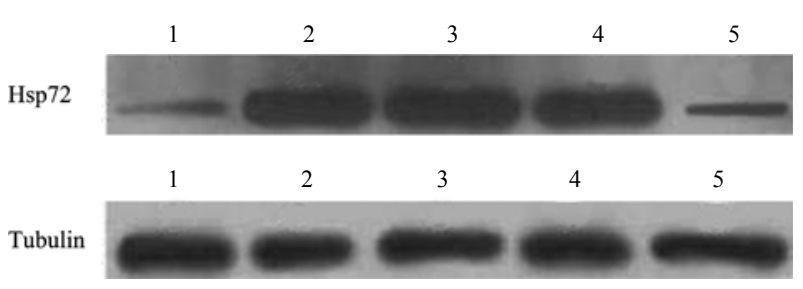

Fig. 2 Hsp70 and Tubulin protein levels were determined by Western blot after the transfection with siRNAs. Proteins were extracted from groups of 200 blastocysts. Lanes: 1, transfected with Hsp72siRN1; 2, transfected with Lamin A-siRNA2 (positive control); 3, transfected with siRNA3 (negative control); 4, only Lipofectamine ${ }^{\mathrm{TM}} 2000$ was transfected (blank control group); 5, $37^{\circ} \mathrm{C}$ group.

Table 2 Relative contents of Hsp72 in each group of embryo

\begin{tabular}{llcccc}
\hline \multirow{2}{*}{ Groups } & \multicolumn{2}{c}{$\begin{array}{c}\text { Optical intensity of } \\
\text { the bands }\left(\times 10^{6}\right)\end{array}$} & $\begin{array}{c}\text { Hsp72/ } \\
\text { Tubulin }\end{array}$ & $\begin{array}{c}\text { Inhibit } \\
\text { rate (\%) }\end{array}$ \\
\cline { 2 - 3 } & \multicolumn{2}{c}{ Hsp72 } & Tubulin & & \\
\hline siRNA1 & $14.16 \pm 0.81 \mathrm{a}$ & $158.91 \pm 3.73 \mathrm{~A}$ & $0.09 \pm 0.04 \mathrm{a}$ & 78.5 \\
siRNA2 & $67.45 \pm 1.25 \mathrm{Ab}$ & $157.10 \pm 3.68 \mathrm{~A}$ & $0.43 \pm 0.04 \mathrm{Ab}$ & - \\
siRNA3 & $67.57 \pm 1.19 \mathrm{Ab}$ & $160.17 \pm 3.68 \mathrm{~A}$ & $0.42 \pm 0.05 \mathrm{Ab}$ & - \\
Blank control & $67.15 \pm 1.29 \mathrm{Ab}$ & $162.27 \pm 3.75 \mathrm{~A}$ & $0.41 \pm 0.03 \mathrm{Ab}$ & - \\
$37^{\circ} \mathrm{C}$ & $24.03 \pm 0.96 \mathrm{c}$ & $163.01 \pm 3.63 \mathrm{~A}$ & $0.15 \pm 0.03 \mathrm{c}$ & - \\
\hline
\end{tabular}

Values are means $\pm \mathrm{SD} ; \mathrm{n}=3$ samples per group. The calculation formula for $\mathrm{Hsp} 72$ protein inhibition ratio is as follows: [1-(Hsp72/Tubulin) $)_{\mathrm{n}}(\text { Hsp } 72 / \text { Tubulin })_{\text {blank }}$ ] $\times 100 \%$. 
Table 3 The developmental rate of the embryos

\begin{tabular}{lccc}
\hline \multirow{2}{*}{ Groups } & $\begin{array}{c}\text { Number of } \\
\text { embryos }\end{array}$ & \multicolumn{2}{c}{ Development rate (\%) } \\
\cline { 3 - 4 } & 100 & Blastocysts & Hatched blastocysts \\
\hline siRNA1 & 100 & $81 \pm 3 \mathrm{~A}$ & $35 \pm 4 \mathrm{~A}$ \\
Blank control & 100 & $86 \pm 5 \mathrm{~B}$ & $72 \pm 5 \mathrm{~B}$ \\
$37^{\circ} \mathrm{C}$ & & $84 \pm 3 \mathrm{~B}$ & $68 \pm 4 \mathrm{~B}$ \\
\hline
\end{tabular}

Values are means $\pm \mathrm{SD} ; \mathrm{n}=3$ samples per group.

\section{DISCUSSION}

The successful introduction of siRNA in the embryo is a crucial part of the experiment in order to achieve an efficient interference. Several techniques have been used to introduce foreign DNA or RNA in an embryo, and the most commonly used technique in mouse oocytes or blastomeres is microinjection (Wianny and Zernicka-Goetz 2000). However, the punctured oocytes are subjected to a physical stress and $10-15 \%$ of the oocytes and zygotes do not survive from the microinjection procedure (Nganvongpanit et al. 2006). Furthermore, it is not efficient to introduce dsRNA into all the blastomeres of embryos at the 4-cell stage and only a single embryo can be microinjected at any one time. Another technique is electroporation (Grabarek et al. 2002), but the application of electric pulses resulted in the release of numerous gas bubbles on the electrodes, leading to degeneration of the treated cells and a survival rate of only $25-30 \%$ (Grabarek et al. 2002). In this study, the transfection method was employed based on its certification as a relatively simple and effective strategy for targeting gene expression in preimplantation embryos (Hannon 2002).

Although murine preimplantation embryos have the ability to take up oligodeoxynucleotides from the culture medium (Dix et al. 1998), time course experiments by Schmajuk et al. (1999) demonstrated that the freeuptake by somatic cells was quite slow. Consequently, several strategies involving the use of Lipofectin, ethoxylated polyethylenimine (EPEI), and Lysolecithin delivery agents were employed in mammalian embryos. Siddall et al. (2002) performed a comparison experiment among the three delivery agents and reported that the treatment of embryos with the agents reduced normal embryonic development to some degree, and the Lipofectin delivery agent reduced development to the least. Furthermore, the experiment results also revealed that the Lipofectin can easily enter into murine embryos.
For these reasons, the Lipofectin delivery agent was selected for the subsequent experiments.

The results of both lower expression of Hsp72 mRNA and Hsp 72 protein in the siRNA1 group and the higher expressions of Hsp72 mRNA in the three control groups of the experiment indicated that the Hsp72 gene was inhibited successfully. Although the blastomeres from 4-cell embryos continued to develop into morula after interference, the blastocysts development rate and hatched blastocysts rate in the siRNA1 group were lower. This indicated that inhibiting the constitutive expression of Hsp72 in preimplantation embryos severely disrupted the developmental competence. One possible explanation may be that early constitutive expression of Hsp72 is required for the cell polarization that takes place following compaction of the embryo. These cell polarizations are required for maintenance of symmetrical axes from zygote to blastocyst (Gardner 1997). Another possibility is that Hsp 72 plays a role in regulating cell cycle and cell death during blastocyst formation. Apoptosis in the inner cell mass is a normal feature of embryonic development (Brison and Schultz 1997); however, there is little information about how these events are regulated. Other Hsp70s have been shown to affect cell cycle and cell death in spermatocytes (Widlak et al. 2007) and somatic cells (Kim et al. 2006a). Since the requirements for Hsp72 expression in the development of preimplantation embryo have been established in this study, the interference model was selected to test hypotheses concerning the Hsp72-dependent mechanism during the development.

The results of detectable expression of Hsp72 mRNA and Hsp72 protein in the embryos cultured under normal temperature in this experiment do not agree with Fourie et al. (2001) and (Rohde et al. 2005) who reported that Hsp72 was expressed at considerably lower or nondetectable levels in unstressed embryos. To our understanding, the preimplantation embryo is most susceptible to certain types of stresses (most notably, heat stress) very early in development when its genome is largely repressed (Tian et al. 2004; Hansen 2002). Thus, the expression of Hsp72 gene is rapidly induced by a variety of physical and chemical stresses such as the temperature alteration and manipulation, and this is also the possible reason to explain why the expression of Hsp72 in embryos in vitro is 5 to 15 times higher 
than that in vivo (Christians et al. 1995).

The significantly higher expression of Hsp 72 mRNA and Hsp 72 proteins in the three heat-stressed control groups demonstrate that the protective mechanism is activated, and the accrescence expression of Hsp72 gene may be one of the protective mechanisms in embryos. The results of slightly higher blastocysts development rate and hatched blastocysts rate in the heatstressed control groups correspond with the findings of Ozawa et al. (2002) who reported that the blastocyst development rate of the embryos cultured in vitro with direct heat stress was slightly higher. All these evidences indicate that the embryos cultured in vitro are sensitive to stressed environment, and the activation of Hsp72 gene may be a basic requirement for embryos to hatch successfully.

The results in this study provide strong evidence that altering Hsp72 gene expression will affect preimplantation development. Neuer et al. (1999) reported that murine blastocysts cultured with Hsp antibodies showed DNA fragmentation more frequently than unexposed embryos, suggesting that apoptosis may be a consequence of embryo toxicity associated with Hsp inhibition. Other studies have shown that developmental expression of Hsp70 is correlated with resistance to apoptosis in response to stress in tumor cells (Jacobs and Marnett 2007; Aghdassi et al. 2007), however, the mechanism still remains to be determined.

\section{CONCLUSION}

The specific siRNA1 designed for Hsp72 gene has significant inhibitory effect. The inhibition rate with Hsp72 mRNA is $87.1 \%$, and with Hsp72 protein, it is $78.5 \%$. Hsp 72 gene silence reduces both the blastocysts development rate and the hatched blastocysts rate after heat shock. Hsp72 has the effect on heat resistance during the development process of mouse preimplantation embryos.

\section{Acknowledgements}

The authors thank the National Natural Science Foundation of China (30571338) for financial support. We also thank Dr. Asabe Dzikwi for correcting the manuscript and Jing Tongquan, Ren Dengliang for their assistance with embryo collections.

\section{References}

Aghdassi A, Phillips P, Dudeja V, Dhaulakhandi D, Sharif R, Dawra R, Lerch M M, Saluja A. 2007. Heat shock protein 70 increases tumorigenicity and inhibits apoptosis in pancreatic adenocarcinoma. Cancer Research, 67, 616-25.

Alizadeh Z, Kageyama S, Aoki F. 2005. Degradation of maternal mRNA in mouse embryos: selective degradation of specific mRNAs after fertilization. Molecular Reproduction and Development, 72, 281-290.

Angelidis C E, Lazaridis I, Pagoulatos G N. 1991. Constitutive expression of heat-shock protein 70 in mammalian cell confers thermoresistance. European Journal of Biochemistry/FEBS, 99, 35-39.

Brison D R, Schultz R M. 1997. Apoptosis during mouse blastocyst formation: evidence for a role for survival factors including transforming growth factor alpha. Biology of Reproduction, 56, 1088-1096.

Cabot R A, Prather R S. 2003. Cleavage stage porcine embryos may have differing developmental requirements for karyopherins $\alpha 2$ and $\alpha 3$. Molecular Reproduction and Development, 64, 292-301.

Christians E, Campion E, Thomson E M, Renard J-P. 1995. Expression of the Hsp 70.1 gene, a landscape of early zygotic gene activity in the mouse embryo, is restricted to the first burst of transcription. Development, 121, 113-122.

Chung J, Nguyen A-K, Henstridge D C, Holmes A G, Chan M H S, Mesa J L, Lancaster G I, Southgate R J, Bruce C R, Duffy $\mathrm{S} J$, et al. 2008. HSP72 protects against obesity-induced insulin resistance. Proceedings of the National Academy of Sciences of the USA, 105, 1739-1744.

Denli A M, Hannon G J. 2003. RNAi: an ever-growing puzzle. Trends in Biochemical Sciences, 28, 196-201.

Dix D J, Garges J B, Hong R L. 1998. Inhibition of hsp70-1 and hsp 70-3 expression disrupts preimplantation embryogenesis and heightens embryo sensitivity to arsenic. Molecular Reproduction and Development, 51, 373-380.

Ewards J L, King W A, Kawarsky S J, Ealy A D. 2001. Reponse of ealy embryos to environmental insults: potential protective roles of HSP70 and glutathione. Theriogenology, 55, 209223.

Fourie A M, Peterson P A, Yang Y. 2001. Characterization and regulation of the major histocompatibility complex-encoded proteins Hsp70-Hom and Hsp70-1/2. Cell Stress Chaperones, 6, 282-295.

Gao X, Zhang P M. 2007. Transgenic RNA interference in mice. Physiology, 22, 161-166.

Gardner R L. 1997. The early blastocyst is bilaterally symmetrical and its axis of symmetry is aligned with the animal-vegetal axis of the zygote in the mouse. Development, 124, 289-301. 
Grabarek J B, Plusa B, Glover D M, Zernicka-Goetz M. 2002. Efficient delivery of dsRNA into zona-enclosed mouse oocytes and preimplantation embryos by electroporation. Genesis, 32, 269-276.

Hannon G J. 2002. RNA interference. Nature, 418, 244-251.

Hansen P J. 2002. Embryonic mortality in cattle from the embryo's perspective. Journal of Animal Science, 80, 33-44.

Hyslop L, Stojkovic M, Armstrong L, Walter T, Stojkovic P, Przyborski S, Herbert M, Murdoch A, Strachan T, Lako M. 2005. Downregulation of NANOG induces differentiation of human embryonic stem cells to extraembryonic lineages. Stem Cells, 23, 1035-1043.

Jacobs A T, Marnett L J. 2007. Heat shock factor 1 attenuates 4hydroxynonenal-mediated apoptosis: critical role for heat shock protein 70 induction and stabilization of Bcl-XL. The Journal of Biological Chemistry, 282, 33412-33420.

Kim J M, Park K H, Kim Y J, Park H J, Kim D M. 2006a. Thermal injury induces heat shock protein in the optic nerve head in vivo. Investigative Ophthalmology \& Visual Science, 47, 4888-4894.

Kim Y K, Suarez J, Hu Y, McDonough P M, Boer C, Dix D J, Dillmann W H. 2006b. Deletion of the inducible 70-kDa heat shock protein genes in mice impairs cardiac contractile function and calcium handling associated with hypertrophy. Circulation, 113, 2589-2597.

Matsuzuka T, Ozawa M, Hirabayashi M, Ushitani A, Kanai Y. 2004. Developmental competence and glutathione content of maternally heat-stressed mouse oocytes and zygotes. Animal Science Journal, 75, 117-124.

Matsuzuka T, Sakamoto1 N, Ozawa M, Ushitani A, Hirabayashi M, Kanai Y. 2005. Alleviation of maternal hyperthermiainduced early embryonic death by administration of melatonin to mice. Journal of Pineal Research, 39, 217-223.

Neuer A, Spandorfer S D, Giraldo P, Jeremias J, Dieterle S, Korneeva I, Liu H C, Rosenwaks Z, Witkin S S. 1999. Heat shock protein expression during gametogenesis and embryogenesis. Infectious Diseases in Obstetrics and Gynecology, 7, 10-16.

Nganvongpanit K, Müller H, Rings F, Hoelker M, Jennen D, Tholen E, Havlicek V, Besenfelder U, Schellander K, Tesfaye D. 2006. Selective degradation of maternal and embryonic transcripts in in vitro produced bovine oocytes and embryos using sequence specific double-stranded RNA. Society for Reproduction and Fertility, 131, 861-874.

Ozawa M, Hirabayashi M, Kanai Y. 2002. Developmental competence and oxidative state of mouse zygotes heatstressed maternally or in vitro. Reproduction, 124, 683-689.

Ozawa M, Yamasaki Y, Hirabayashi M, Kanai Y. 2003. Viability of maternally heat-stressed mouse zygotes in vivo and in vitro. Animal Science Journal, 74, 181-185.

Paradis F, Vigneault C, Robert C, Sirard M-A. 2005. RNA interference as a tool to study gene function in bovine oocytes. Molecular Reproduction and Development, 70, 111-121.

Rohde M, Daugaard M, Jensen M H, Helin K, Nylandsted J, Jäättela M. 2005. Members of the heat-shock protein 70 family promote cancer cell growth by distinct mechanisms. Genes \& Development, 19, 570-582.

Schmajuk G, Sierakowska H, Kole R. 1999. Antisense oligonucleotides with different backbones. The Journal of Biological Chemistry, 274, 21783-21789.

Siddall L S, Barcroft L C, Watson A J. 2002. Targeting gene expression in the preimplantation mouse embryo using morpholino antisense oligonucleotides. Molecular Reproduction and Development, 63, 413-421.

Stein P, Svoboda P, Anger M, Schultz R M. 2003. RNAi: mammalian oocytes do it without RNA-dependent RNA polymerase. $R N A$, 9, 187-192.

Svoboda P, Stein P, Hayashi H, Schultz R M. 2000. Selective reduction of dormant maternal mRNA in mouse oocytes by RNA interference. Development, 127, 4147-4156.

Thayer J M, Mirkes P E. 1997. Induction of Hsp72 and transient nuclear localization of Hsp73 and Hsp72 correlate with the acquisition and loss of thermotolerance in postimplantation rat embryos. Developmental Dynamics, 208, 227.

Tian W R, Du L Y, He J B, Li S J. 2004. Inhibition of HSP70 gene expression by modified antisense and its effects on embryonic sensitivity to heat shock. Agriculture Sciences in China, 3, 149-155.

Wianny F, Zernicka-Goetz M. 2000. Specific interference with gene function by double-stranded RNA in early mouse development. Nature Cell Biology, 2, 70-75.

Widlak W, Vydra N, Malusecka E, Dudaladava V, Winiarski B, Scieglinska D, Widlak P. 2007. Heat shock transcription factor 1 down-regulates spermatocyte-specific $70 \mathrm{kDa}$ heat shock protein expression prior to the induction of apoptosis in mouse testes. Genes to Cells, 12, 487-499.

Xu Z, Williams C J, Kopf G S, Schultz R M. 2003. Maturationassociated increase in IP3 receptor type 1: role in conferring increased IP3 sensitivity and $\mathrm{Ca}^{2+}$ oscillatory behavior in mouse eggs. Developmental Biology, 254, 163-171.

Yu J Y, DeRuiter S L, Turner D L. 2002. RNA interference by expression of short-interfering RNAs and hairpin RNAs in mammalian cells. Proceedings of the National Academy of Sciences of the USA, 99, 6047-6052.

Yu Y, Yong J, Li X, Qing T, Qin H, Xiong X, You J, Ding M, Deng H. 2005. The proteasomal inhibitor MG132 increases the efficiency of mouse embryo production after cloning by electrofusion. Reproduction, 130, 553-558. 